\title{
特別講演（文化）：鵜匠・山下純司氏 「鵜と鵜匠の語らい」の講演を聞いて
}

平成 18 年度の第 14 回プラスチック成形加工学会秋季大 会・成形加工シンポジア’06の特別講演（文化）が 11 月 22 日（学会の第 1 日目）の午後 4 時 20 分から, I 会場で 開催された。参加人数は約 310 名で, 講演会場はほぼ満席 の状態だった。宮内庁式部職・鵜の庵 “鵜” ・鵜匠代表 • 山下純司氏および鵜に来学いただき，鵜匠の衣装で，岐阜 の風物文化である長良川の鵜飼について御講演をいただい た様子と講演の概略を以下に記述する。

\section{はじめに}

鵜飼は，約 1300 年続いた日本の伝統であり，野生の鵜 と鵜匠を通じて自然の営みに繋がり, 現代まで受け継がれ てきた。鵜匠は，伝統漁法の担い手として宮内庁に属し， 鵜飼始めに，皇室に鮎を献上するとともに，長良川鵜飼は， 岐阜の重要な文化の一端として，人々に親しまれている。

\section{鵜 と鵜 匠}

鵜匠は世襲の職であり，長良川鵜飼では 6 家が伝統を引 き継いでいる，各家にはそれぞれの考えがあり，生活の中 で自分で学び，身上に従って独自性を出して行くことで, 長きにわたり長良川鵜飼を受け継いできた. 今後も時代と 伴に変化し，柔軟に鵜匠を受け継いでいくことになる.

鵜匠の家では，野生の鵜と生活の中で語らうことにより， 幼い頃より成長していく，鵜には名前が無く，鵜匠が姿・ 特徵を見て認識し，鵜ごとの記録も無く，現状での各鵜の 能力に合わせて仕事を割り当て，一緒に行う。鵜の扱い・ 漁法についても絶対的なものは無く, 各人が経験の中で学 ぶ. 若い頃, 鵜匠の多くは, 自分流の多くの新しいことを 模索するが，長年の内に先人の手法が優れていることを体 得する．試行錯誤は，より深い知識の理解・実現に大きく 寄与する.

\section{鵜飼について}

鵜飼の時, 鵜匠は鵜と語らって, 当日に働く鵜（10〜12 羽）を決める.鵜と鵜匠で丁度合っていることが重要で, 鵜 のとる魚量と鵜匠のさばき量が対応し，良い仕事ができる. 魚量は,多過ぎても少な過ぎてもあまり良いことではない. 鵜と鵜匠は手縄(たなわ)で結ばれており, 鵜匠は手縄さ

\footnotetext{
Mimatsu, Junji

岐阜大学 工学部 機械システム工学科

岐阜市柳戸 1-1（テ501-1193）

2006. 12.11 受理
}
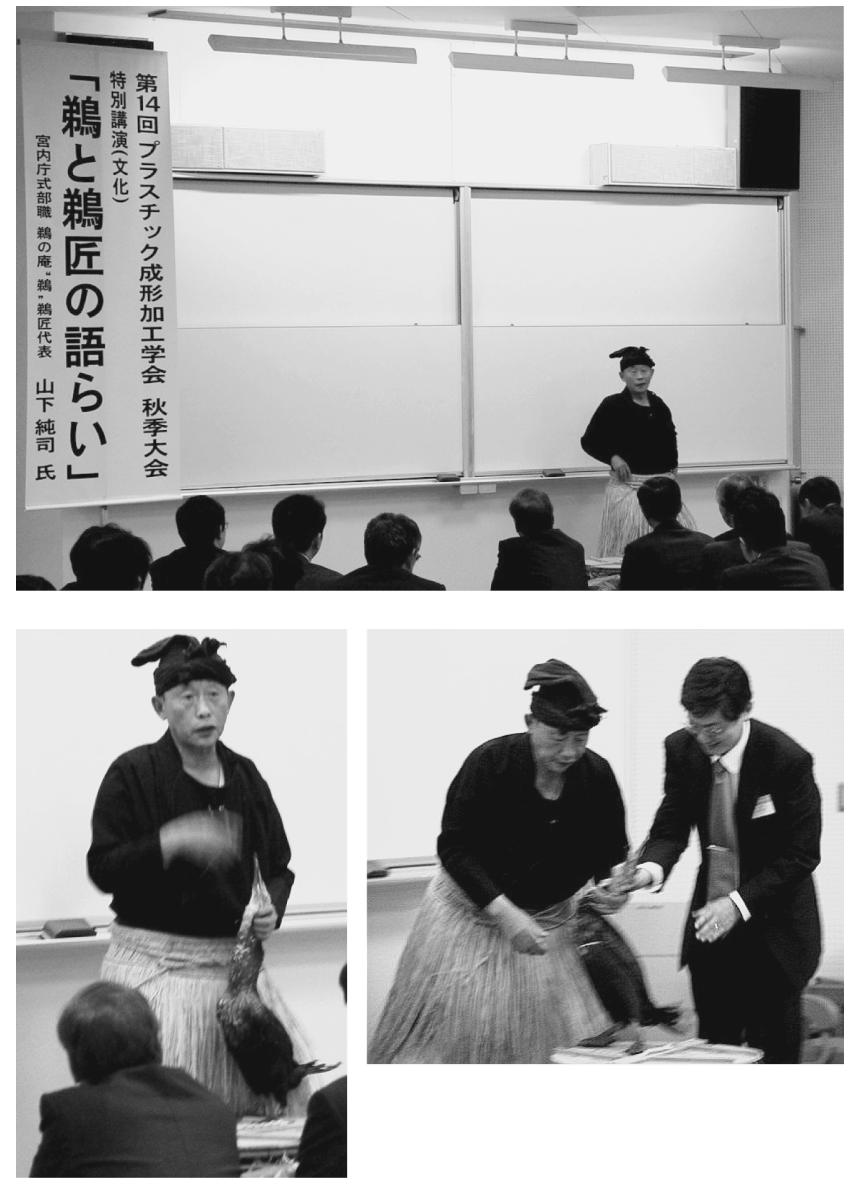

特別講演（文化）の様子 1

ばきで鵜を操り,鮎を捕る.手縄は強度を保つとともに, 鵜 が引っ掛かった場合，逆方向に捻ることにより，容易およ び即座に切断し，鵜を緊急的に解き放つことも可能である。 近年，長良川の魚は減少しており，昔のように多くの魚 を取ることを見せるには, 鵜の頑張りと鵜匠, 鵜舟操り手 の連携が必要である，川の状況を体得し，同じ呼吸でない と魚をとることは難しい. また，見せるために魚を多くと ることが本当に自然の摂理に合っているか充分に考える必 要がある。

昔は，魚をとる漁法の一つであったが，最近は，見せる ものにもなっている. 鵜と鵜匠の共同作業として考え, そ の姿から，自分で何かを掴んで貪えるならば良いと思う. 


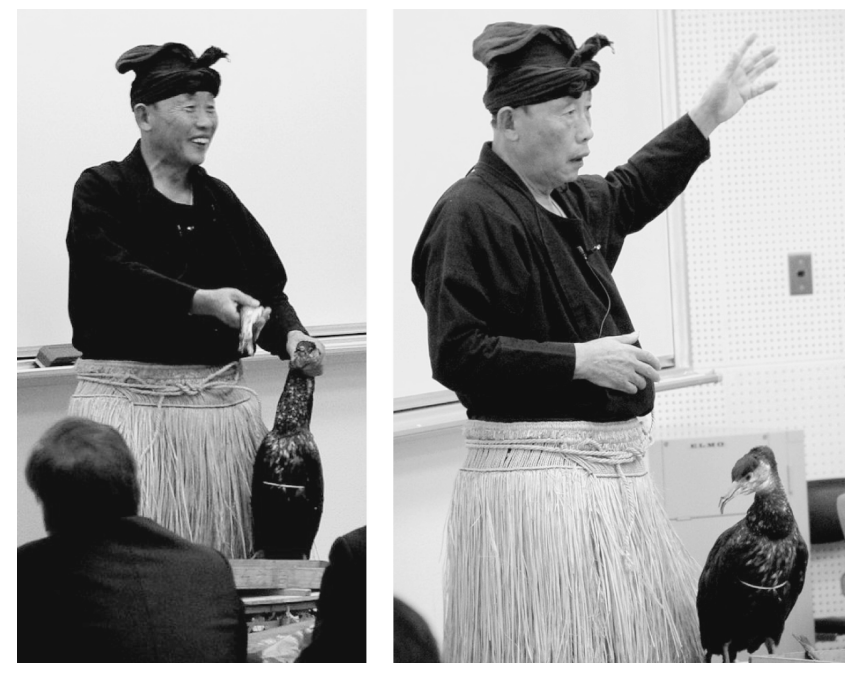

特別講演（文化）の様子 2

\section{語らい}

鵜と鵜匠の関係で重要なことは，“語らい”である，近 来の社会で希薄になっている相手との心情を含む相互間の 交流状態・信頼関係が，最も基本的な “語らい”である. 鵜は言語で喋らないけれども，態度・雾囲気で，人間以上 に直感的に感じ・示すので，率直な交流に必ずなる．現代 社会で失われつつある信頼関係の原点が存在する. 親と子, 教師と生徒，上司と部下などの間に同様の関係が見受けら れないのは, 最近の世情を反映している.

昔, 家では, 家族の寝床・洗濯を手で行い, その時, 各 人の体調を湿り・匂いで感じ取り, 合わせて料理, 食物, 塩加減を工夫し，家族全員の健康を維持してきた．流域の 作物をとることにより, 自然の営みを体内に得て, 人間も 自然に活力を与えてきた。これが, “語らい”の原点であ

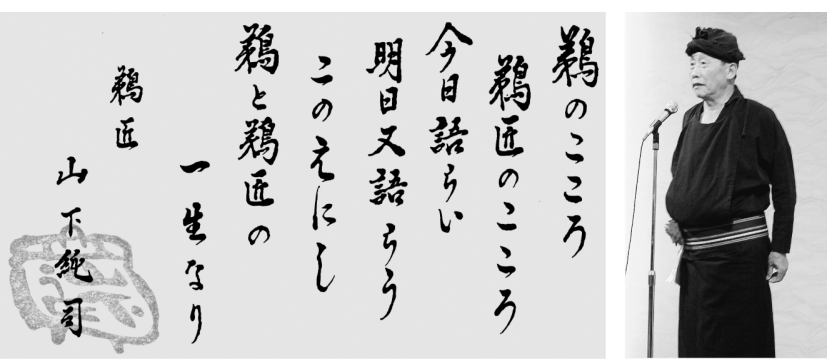

鵜のこころ, 鵜匠のこころ

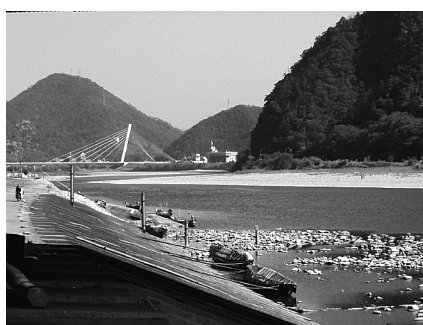

鵜飼を行う長良川の流域 (長良橋下より撮影)

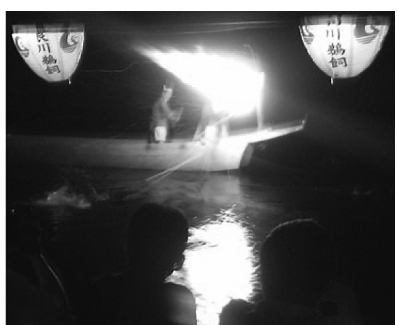

鵜飼（参考写真）
り，各人が，何時も衣服・布団の温かみに，親の恩顧を感 じて真っ当に生きていた．鵜が消化できるものは下から， 消化不可のものは上から出すことにより, 鵜匠は, 鵜の生 活環境を清掃する時に，鵜の現状，成長，退化などを体得 し, 鵜も鵜匠の世話心を感じ取り, 鵜飼において, 共同作 業により，頑張ることができる.

\section{自然と人間}

人間は本来，自然と一緒に生き，一緒に暮らしてきた者 である，日々の生活は，ある意味で単調であるが，災害・ トラブルが皆無ということは無い.ただし，それは“縁(え

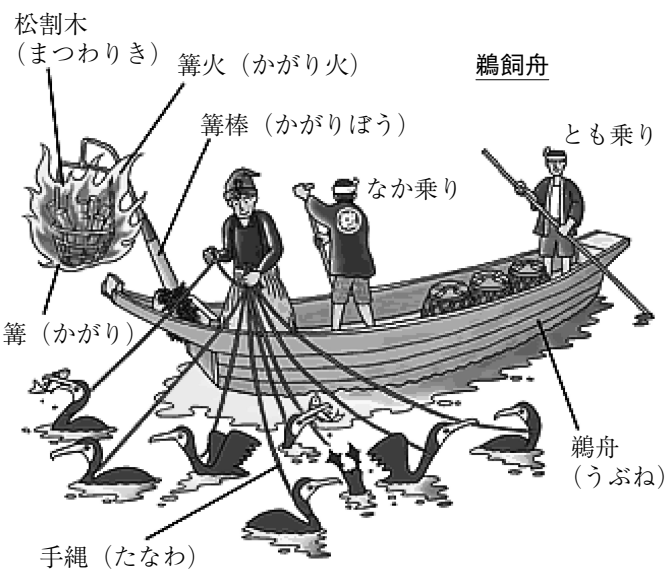

長良川鵜飼舟の構成

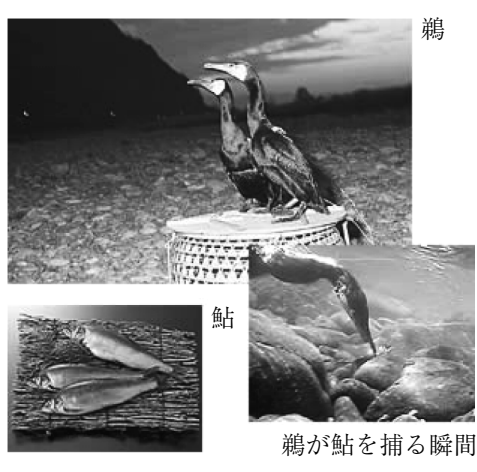

長良川鵜飼の鵜

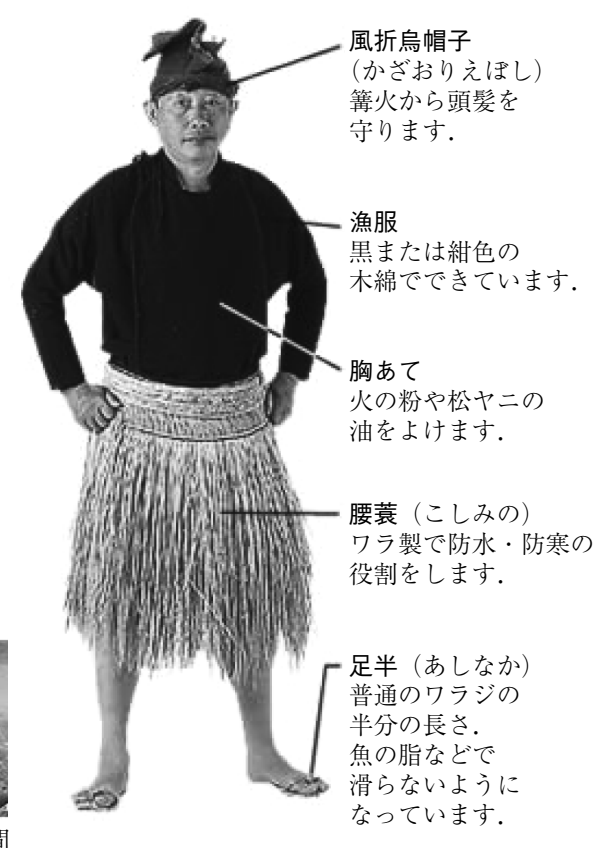

長良川鵜飼の鵜匠の衣装

*これらの 3 つの図の写真及び挿絵など（提供：岐阜市, HP から許可を得て転載 ${ }^{1}$ ) 
ん)”であり，人生で，より高貴を目指して成長するため の出来事であり, 不可避なことである. 川に堤防を築いて 災害を防ごうとしても自然の摂理に反することであり，よ り多くの不利益を生じさせていることもある.川が蛇行し ながら流れるのは, 自然の摂理であり, 洪水を許容しなが ら，田畑を潤し活性化する，自然に任せることで，昔は川 に魚が湧く状態であったが，昨今は，自然が失われ，その ようなことは無い.

人間がつくるものには, 自然に同化して行くものと相反 するものがある. 自然的生活が好ましいものであり, 地中 梁くの化石燃料の公害など, バランスを崩すものは, 負の 大きな遺産を残すので，人間は自然に対して謙虚であるべ きものである。また，各自が生まれてきた“縁（えん） により, 現世で行う使命が与えられているので, 生活し衣 食住のために働き，準備を行い，自分なりの役割分担（使 命）をなすべきであり，定年になって燃え尽きるようにな るのは, 人間として，本当の意味では生きていない.

\section{ぜひ長良川鴉飼を，実際に御覧になって堪能して下さい.}

鵜匠の山下氏には, 大変ご多忙の中, 今回の特別講演(文
化）を引き受けていただき，厚く御礼申し上げます。色々 と至らぬことを，寛容に御対応いただき，心より感謝申し 上げます。

鵜飼舟について (補足)

鵜舟は鵜匠のほかに, 助手の「なか乗り」と舟の舵をと る「とも乗り」を加えた 3 人 1 組で構成されている.

【鵧舟】全長約 13 メートルで, 3 人が 1 組なる。【篝火】 鵜飼の照明.【篝】篝火を燃やす鉄製のかご、【篝棒】篝を ぶら下げる.【松割木】照明用に使う松の割木.【手縄】鵜 を操るときに使う縄.【とも乗り】鵜舟を操縦する責任者. 【なか乗り】2 名の助手.

鵜飼の衣装について(補足)

鵜匠の正装は，かがり火から髪の毛を守るために風折鳥 帽子をかぶり，漁服（黒または紺の木綿）を身にまとい， 火の粉を防ぐ胸あてをつけている. 腰から下は腰蓐をつけ るなど，古式ゆかしい装束である（（鶫匠の正式な衣装） 長良川鴉飼の開催期間 例年は 5 月 11 日〜 10 月 15 日です.

\section{参 考 文 献}

1) http ://www.city.gifu.gifu.jp/kankou/ukai_00.html

\section{「目でみる結晶性高分子入門」}

アグネ技術センター

A 5 版・並製 280 頁
成形加工の分野では可視化技術が大きな役割を果たしてい る.このことは科学や技術の原点がなによりも目で見て観察 することから始まることを示している. 高分子科学の発展の 歴史のなかでは, 1960 年代にポリエチレンの単結晶が発見 されたことが大きな話題となっていた. 結晶化する高分子が あることはX 線回折などにより古くから知られていたが, その結晶は房状ミセルといわれる, 規則正しく分子鎖が伸び て配列した部分が混在するようなモデルが推定されていた. 電子顕微鏡で観察された単結晶は分子鎖が折りたたまれるこ とでできているものとして, 従来の高分子の結晶構造に対す る考え方を一変させた。 ほかの結晶性高分子についてもポリ エチレンと同じような単結晶ができないものかと模索された が, 著者はポリプロピレンでも条件を絞ることによってやは り単結晶ができることを初めて示した研究者として知られて いる. 単結晶の発見以来, 高分子の結晶構造やその成長機構 などについての研究は飛躍的に進んだが, 著者は電子顕微鏡 を駆使することで, ポリプロピレンやポリフォスファゼンを
小島盛男著 定価 3,150 円（本体価格 3,000 円+税）

対象として結晶性高分子のモルフォロジーといわれる高次構 造に対して, 熱処理や延伸あるいは成形加工の影響を観察し, さらには変形や破壊で結晶がどう変化して行くのかを追及し た結果を成果としてまとめたものが本書である。これだけ電 子顕微鏡写真が採録されている本もめずらしい. “百聞は一 見に如かず”というょうに，まさしく目で見ることの楽しさ を今更ながらに味わうことができる．著者もあとがきで述べ ているように，多種類の高分子のなかでこのように見ること のできる高分子は例外かも知れない. また, 電子顕微鏡の観 察では，見たいところを強調するための前処理をとることも 多いので, 実は見えない部分の振る舞いがとくに機械的性質 を左右することを忘れてはならないが，高分子科学を専攻す る学生にとっては結晶性高分子を知ってもらうためには好個 のテキストになるものである. また，すでに高分子の世界に なじんでいる人にとっても, アルバムをひも解くような懐か しさでページをめくることのできる本でもある.

（山形大学 成澤郁夫） 